\title{
¡Penuria! ¡Dolencia! ¡Escasez! o el Alboroto y Motín de 1692 en la Ciudad de México
}

\author{
Penury! Disease! Shortage! or the "Rampage and Riot" of 1692 in Mexico City
}

\section{Vidzu Morales Huitzil ${ }^{1}$}

Fecha de recepción: 06-01-2020

Fecha de aceptación: 22-09-2020

Entre la pesadumbre que me angustiaba el alma, se me ofreció [...] como [...] Troya, cuando la abrasaron los griegos.

Carlos de Sigüenza y Góngora

\section{Resumen}

El objetivo de este artículo es comprender tanto la objetivación como formalización del documento histórico nominado Alboroto y Motín de México, por ende, se pretende enfatizar el foco narrativo de don Carlos de Sigüenza y Góngora. Con ello, se explicitan los matices discursivos en la epístola del sabio novohispano, constituyendo una crítica a la historiografía de tinte ético.

Palabras clave: Historia, motín, siglo XVII, Nueva España, género epistolar

\begin{abstract}
The purpose of this article is to comprehend both the objectification and the formalization of the historical document named Alboroto y Motín de México, therefore, it is intended to emphasize the narrative focus of Don Carlos de Sigüenza y Góngora. Thus, the discursive nuances in the epistle of this erudite of New Spain are clarified, making a critique of the historiography with ethical overtones.
\end{abstract}

Key words: History, mutiny, XVII century, New Spain, epistolary genre

\footnotetext{
1 Licenciado en Historia, Doctor en Literatura Hispanoamericana, Benemérita Universidad Autónoma de Puebla, México. Correo electrónico: vidzu1@hotmail.com
} 


\section{Introducción}

Es siete de Junio de 1692, y una elevación ingente de mar se abalanza sobre Jamaica; ese mismo año, en el tono convulso de la historia, don Carlos redacta una epístola que dará cuenta sobre las tensiones sociales en la ciudad de México. Dicho opúsculo contiene en su nominación una referencia del acaecer en cuanto su distención e intención, es decir: Alboroto y Motín de México. Por lo cual, siguiendo el Tesoro de la Lengua se apercibe la secuente acepción respecto alboroto: "Lat., tumultus, vale alteración de gente, ruidoso, vocería, pendencia, [...] el padre Guadix dice que al-y borod, que vale polvareda, porque la gente alborotada con el movimiento de los pies levanta mucho polvo, [...] alborotado, el que está con la pasión y enojo inquieto" (De Covarrubias, 1611, p. 105). En cuanto la significación del vocablo motín se concibe "la alteración de soldados y gente de guerra, dícese en latín motus. Esto suele suceder por deberles muchas pagas, y particularmente en los que son conducidos en forma que están siempre aparejados para quien mejor les hiciere" (De Covarrubias, 1611, p. 1152). De este modo inscribe un movimiento, representado mediante una écfrasis ${ }^{2}$ referencial pretérita, al enfatizar el descontento y la exigencia ante la ingente hambruna. Así, la corporeidad de los disidentes es capital para comprender el asombro ante una tendencia irregular dentro del entramado virreinal.

\section{Perspectiva historiográfica respecto al opúsculo de Sigüenza}

A este escrito diversos estudiosos le han integrado estatutos éticos sobre los apelativos que el polímata esgrime a los indígenas, empero, ¿es propicio que el afecto aflore en una investigación del acaecer pretérito?
A don Carlos se le ha tachado siempre de una insana predilección por los vetustos habitantes del altiplano y una grima ante las castas coetáneas. Sin darse cuenta de que en la epístola introduce desde españoles hasta negros en su consideración infame, y el hecho de puntualizar a los indígenas, dentro de una pésima nominación, se debe más a un asunto demográfico, imperial, y de carácter agencial que responden al sostén de una potencia política (ique la razón no sea invalidada por constituyentes éticos!). Sobre este punto, se asevera que don Carlos reconoce en dicha casta novohispana epítetos solemnes; v.gr. en el Paraíso Occidental se apercibe el reconocimiento volitivo dentro de los cánones cristianos en algunas monjas del convento de Jesús María (condición que las eleva más allá de su categorización fisiológica). Del mismo modo, en el libro tercero capítulo décimo sexto del referido opúsculo (Refiéranse algunos suceso de la M. Abadesa Antonia de Santa Clara y su Devoción al Santísimo Sacramento) funge como medio salvífico, y emisario teofánico, para que las flores del pénsil conventual no perecieran en la hambruna de México de 1629 a causa de anegación: "afligida la buena prelada, convocó a sus monjas y llevándolas al coro les dijo pidiesen al santísimo sacramento, enviándoles por mano de una india una gran canoa de maíz, con que remediaron el hambre" (De Sigüenza, 2003, p. 188).

Ante ello, no podemos negar la razón práctica del polímata que, siguiendo a Giovanni Francesco Gemelli Careri en su Giro del Mondo, era un reflejo de caridad frente a los estratos más necesitados. Es decir, no aseveramos un inmaculado actuar en don Carlos, pero, se busca una concepción factual más acorde a su vida y obra. A ello, nuestro polígrafo concreta la diferencia entre habitus y natura de los indígenas en el Prólogo al Lector del tan afamado Paraíso Occidental: "me hallo con cierta ciencia

2 Luz Aurora Pimentel versa sobre la écfrasis lo secuente: "El sentido original de esta figura, tal y como lo entendían los rétores de los siglos III y IV d.C, y en especial Hermógenes, en su Ecphrasis, Progymnasmata, quedaba definido dentro de las formas de la descripción: se trataba de una descripción extendida, detallada, vívida, que permitía 'presentar el objeto ante los ojos;' una descripción que tenía la virtud de la energeia [...]Ahora bien, en tanto que representación, el objeto plástico descrito verbalmente puede ser, como bien lo advierte Clüver, real o ficticio; de hecho el paradigma mismo de la écfrasis, el escudo de Aquiles en la Ilíada, no existe fuera de la descripción que lo construye. De tal suerte que podemos hablar de écfrasis referencial, cuando el objeto plástico tiene una existencia material autónoma, o de écfrasis nocional cuando el objeto "representado" solamente existe en y por el lenguaje, como en el caso del escudo de Aquiles. Hay, sin embargo, un tipo de écfrasis intermedia que yo querría llamar écfrasis referencial genérica, y que con frecuencia se observa en textos ecfrásticos que, sin designar un objeto plástico preciso, proponen configuraciones descriptivas que remiten al estilo o a una síntesis imaginaria de varios objetos plásticos de un artista [...] Por su parte, la écfrasis nocional produce la ilusión de un objeto plástico autónomo y silencioso que pide y se presta a ser descrito, re-presentado" (Pimentel, Luz Aurora. (2003). "Ecfrasis y lecturas iconotextuales.”, Poligrafías - Revista de Literatura Comparada, $\mathrm{N}^{\circ}$, México: UNAM, pp. 206-208) 
de las idolatrías, supersticiones y vanas observancias en que hoy entienden, y de que me alegrará me mandasen escribir para su remedio" (De Sigüenza, 2003, p. 48) [...] "viérase entonces ser la causa y el origen de tanto daño el detestable pulque, de cuyo uso, de ninguna manera indiferente, sino siempre pecaminoso" (De Sigüenza, 2003, p. 48). El insigne polímata, considera que los sujetos deben integrarse dentro de un orden deóntico - religioso que optimice el entramado virreinal, por ende, para don Carlos la constitución imperial no es un problema, ya que buscó el auge geopolítico de su patria y no precisamente el bienestar individual, condición que se afianzó en el siglo pasado. Ahora bien, esto no niega la vociferación in malam partem o el sentimiento de misericordia por parte de Sigüenza, que se encuentra en el libro primero, capítulo séptimo del ya nominado Paraíso Occidental:

la grande mortandad de Indios, que destruyó estas provincias, causada de querer congregarlos a nuevos sitios, quemándoles para ello sus pobres casas, desposeyéndolos de sus bienes, tan lastimosamente, cuanto lo publican las ruinas de sus Pueblos, que no pueden ver los ojos sin que se aneguen en lágrimas. (De Sigüienza, 2003, p. 124).

Por ende, en su eutaxia ${ }^{3}$ la individualidad se subsume a la particularidad y a su vez, esta última se encuentra dentro del estamento colectivo; don Carlos crea un cuadro inteligible del poder, que no le impide un dejo de misericordia, de admiración o comprensión ante el indígena contemporáneo, empero, todo ello debe encontrarse en un podio anterior al fin factual que decantaría en la potestad de su patria.

Y ¿ por qué se le adjudica a don Carlos determinados epítetos? Se responde a tal cuestionamiento: La péndola de muchos autores se engalana con la grafía ideológica, la enajenación del lenguaje y su incomprensión de los estadios crónicos del mundo. Don Carlos en su complejo estema factual, jser humano, al fin y al cabo!, continuamente reposiciona al indígena, es decir, lo que enuncia de dicha casta en la prosa histórica, no puede denominarse y no al mismo tiempo, por lo tanto, su consideración etopéyica
- escritural es, en cierta medida, un referente histórico en específico y no a una sustantivación de las castas. El indígena no puede ser al mismo tiempo nefando y fasto, por lo que se concreta axiológicamente, respecto a los elementos propios de su acaecer, a la péndola del egregio historiador.

\section{Sobre el género epistolar}

Se debe comprender el lugar de enunciación, desde el cual se traslapa la péndola del ingente filomomo, para vislumbrar la epístola como una organización conceptual que devela la operatoriedad de un proceso histórico. Es decir, esta constitución escritural pone de manifiesto casi dos siglos de revueltas entre las que encontramos las secuentes: a) la distensión de la periferia imperial (Cataluña, Brasil, Portugal, el tumulto de 1624); b) la presunta intriga virreinal por parte del virrey don Diego López Pacheco y Braganza; c) la querella ejercida por los conquistadores; d) la trama de Guillén de Lampart; e) la conjura de negros (1537, 1602, 1612); la ablación política de mestizos y mulatos (1664-1666); f) la insurrección indígena (1601, 1610, 1616, 1639, 166o, 1684, 169o) (Obregón, 2015).

Por ello, el género epistolar es tan revelador en este caso (de ahí su confrontación documental con otros escritos del polímata), ya que existe una apreciación crónica respecto a la vida del autor, el actuar de sus contemporáneos, la viveza de las ideas imperantes, la apreciación de la subsistencia y el fenecimiento a finales del siglo XVII novohispano. En la Nueva España, "la Historia no es unidimensional y sucesiva, sino un sistema plural y heterogéneo, lleno de inesperadas articulaciones, conexiones laterales, súbitas convergencias y fértiles regresiones" (Oviedo, 2007, p. 27). Dicha complejidad se apercibe en la estructura epistológica encabezada por el exordio, donde se establece un pacto de información, que puede o no ser reconocido por el destinatario (Capitán Andrés de Peza); se procede a la narratio que enfatiza una disposición de ciertas factualidades para concretar una racionalidad en el lector mediante la argumentatio; finalmente se vislumbra la peroratio (fechada el 30 de Agosto de 1692) que, si se 
concibe bajo la importancia de lo anteriormente tratado, respecto a los fines programáticos ${ }^{4}$, se comprende su conminación proléptica plausible.

Por ende, se debe tener en cuenta que el ya mencionado destinatario epistolar sostuvo una relación de orden gubernamental, y posiblemente cercana, con el sabio novohispano, debido a la necesidad de la estructuración septentrional y del seno mexicano; estratega y pensador yacían bajo la potestad del virrey Conde de Galve (un año después entrambos partirían a la bahía de Panzacola para cartografiar y planear un posicionamiento militar frente a los castrenses franceses e ingleses). Así, ciertas estructuras a las que don Carlos se acopla se encuentran ya descritas en el tratado Sobre el Estilo (Siglo III a.C. ¿? - Siglo I d.C. ¿?) de Demetrio: "proximidad al diálogo / estilo simple / claridad y brevedad / estructura flexible / temas propios / expresiones de amistad" (Arcos, 2008, p. 349). Esta braquilogía a la que nuestro polímata se encuentra acostumbrado, y de la que ha hecho mención con anterioridad, se concreta en su epístola (condición que encontrará sus matices debido a la ingente subjetividad del documento en cuestión). La carta apela a un sentir común, debido a la cuasi - presencia del Capitán Andrés de Pez, articulado en la experiencia por la ya conocida "definición de Cicerón: conloquia amicorum absentium (Phil. 2.7) (conversación de amigos ausentes)” (Arcos, 2008, p. 351). Esta red conceptual, no isomórfica sino nodal, permiten el sentido epidíctico in malam rem sobre los agentes generadores del motín, condición que se encuentra en la persuasión del ecofonema, es ese salir de uno con vehemencia, donde el arrebato refiere a la impotencia por la situación acrática del orden virreinal: "¿Qué otra cosa fue la fatalidad lastimosa con que quedará infame, [...] sino llegar a lo sumo los desdenes con que comenzó la fortuna a mirar a México, sin más motivo que haber sido esta ciudad nobilísima teatro augusto" (De Sigüenza, 1986, p. 151). Siendo un deíctico espacial con la capacidad de trasladar una écfrasis noética, en una factualidad imperante, que periclita frente a la turba iracunda, como asegura don Carlos: "Con este presupuesto le aseguro a Vmd. con toda verdad no haber tenido que envidiar México a otro cualquiera lugar que no fuere esa corte de Madrid (donde no hubo representación sino realidad)" (De Sigüenza, 1986, p. 160).

4 En el sentido que afirma Jesús G. Maestro en su teoría literaria
De ahí que don Carlos, se presente como medio para dar a cuenta los procesos factuales que impiden el refocilar del polímata, lo que instituye un puente de transmisión referencial que Sigüenza se adjudica en el orden misivo de un pacto filial: "Hago aquí punto para advertir antes a los que acaso leyeren ésta lo que ya sabe Vmd. porque, mediante nuestra amistad antigua, me conoce muy bien” (De Sigüenza, 1986, p. 152). Con ello, se presenta el dinamismo ciceroniano de la epistología ("Illud, quod est epistulae propium, ut is ad quem scribitur de iis rebus quas ignorat certior fiat, praetermittendum esse non puto / Cic. Q. fr. 1.1.37 / No pienso que se deba pasar por alto lo que es propio de la carta. Informar al que se escribe de aquellos asuntos que desconoce") (Arcos, 2008, p. 353). Se apela a que la comprensión factual solamente se puede dar bajo los estatutos del condicionamiento conceptual, el mundo denominado alcanza una mayor claridad bajo la perspectiva del consumado acaecer, tanto en la racionalidad como en la comprensión de la experiencia, así la Historia es inteligible en un ordenamiento cognoscitivo: "Los anteojos que yo uso son muy diáfanos, porque viviendo apartadísimo de pretensiones y no faltándome nada, porque nada tengo, sería en mí muy culpable el que así no fueran” (De Sigüenza, 1986, p. 152). El último apartado remite a la presentación de cierta franqueza por parte de don Carlos, es una develación de que su etopeya cronográfica es la ideal para plasmar la cronografía, "como afirma Cicerón: epistula non erubescit / la carta no siente vergüenza / Cic. fam. 5.12.1.) (Arcos, 2008, p. 353).

Con ello, se afirma una suerte de narración que oscila entre la diégesis que impele a la acción motu proprio, el actuar ajeno, pero, visualmente cercano, y los elementos completamente no vivenciales:

No hay medios que me tiñan las especies de lo que cuidadosamente he visto y aquí diré, desde luego me prometo, aun de los que de nada se pagan y lo censuran todo, el que dará asenso a mis palabras por muy verídicas. (De Sigüenza, 1986, p. 152).

En el tercer rubro, el acaecer que se rememora como un proceso mnemotécnico - factual, objetivado en los logros del virrey de Galve y los agentes históricos fundamentales 
para la génesis del motín, es un basamento agencial para el entramado diegético epistolar. En este apartado se alude a que la maquinaria virreinal ha desencadenado, prefigurando y configurando novísimos estadios que permiten su ennoblecimiento ("Todo sucedió como el deseo quería, porque sólo le asistía el deseo de acertar en todo") (De Sigüenza, 1986, p. 152). A su vez, bajo la suma potestad del virrey, Sigüenza enfatiza que don Pedro Osorio de Cervantes (sargento mayor de la Armada de Barlovento) reforzó la provincia de Yucatán, en especial la villa de San Francisco de Campeche; y que el conde de Galve ordenó el apoyo a los presidios septentrionales. Con ello, existe una relación entre dicha epistolografía y dos de sus obras, El Mercurio Volante y el Trofeo de la Justicia Española, trinomio que funge como péndola imperial, haciendo comprensible al poder sus dinamismos y alcances, y reconociendo en su cronología una capacidad propia para tal faena ("No hay quien no desee el acierto en lo que maneja, pero como su consecución consiste en ápices, lo consiguen pocos") (De Sigüenza, 1986, p. 154).

\section{Alboroto y motín de 1692 en la ciudad de México}

Don Carlos comprende los alcances de la volición y de la no indeterminación crónica (caso que no mitiga de ningún modo la Parusía), debido a que la armada virreinal, aunque se trasluce como contención a una distensión imperial, no logra su cometido frente a los condicionamientos estructurales por los cuales la praxis desentrañan futuribles. Dichas discreciones factuales, encuentran un dejo epidíctico in bonam partem cuando el virrey, logra, bajo la volición y la racionalidad, algunos triunfos en el septentrión novohispano, en el cual la cualidad acrática de los vetustos mexicanos, se acentúa frente al establecimiento nómico de poblaciones ajenas al poder virreinal.

Paréceme no igual, sino superior a lo antecedente, la felicidad de haberse puesto en doctrina y policía a los indios chichimecas de la Sierra Gorda, en tiempo de su gobierno" (De Sigüenza, 1986, p. 159) debido a que su sujeción no la habían conseguido "ni los mexicanos cuando floreció su imperio (De Sigüenza, 1986, p. 159).
La explicatio del pretérito presente, por ende, introduce al destinatario en los ejes de concatenación crónica que han brindado una cierta estabilidad, y una potestad capaz de asemejarse a la metrópoli, condición que se irá resquebrajando en el desarrollo narrativo. Con ello, los posicionamientos cronográficos se encuentran delimitados en una formalización epistolar, de este modo, se plantea el escenario en el cual el actuar, mediante una descriptio loci y su cronografía, decantará en la revuelta futura. Así, la péndola de Sigüenza abre una pronunciación ecofonémica, introduciendo la complejidad para la constitución del discurso histórico; donde la suma de cronicidades no implica una regulación de la factualidad per se, ya que en su confluencia se ubica una dialéctica -antitética irreductible a los posicionamientos pretéritos - presenciales (“¡Cuánto, oh, Dios mío santo y justísimo, cuan apartados están del discurso humano tus incomprensibles y venerables juicios, y cuánta verdad es la de la Escritura, que con la risa se mezcla el llanto, y que a los mayores gustos, es consiguiente el dolor!") (De Sigüenza, 1986, p. 161).

Por ende, en la génesis de la revuelta el tono de don Carlos integra a la totalidad de castas ante el sentir disfórico que azotó la ciudad de México, en tanto que, sin importar el epíteto, los hogares indígenas e hispanos comenzaron su desolación por las desbordantes afluencias. Las lluvias desbordaron el riachuelo nominado de los Remedios, "llevándose consigo cuando encontraba, sin privilegiar las casas de los indios, por ser muy débiles, ni a las de los españoles, que estaban por las lomas y valles, por ser robustas" (De Sigüenza, 1986, p. 162). El destinatario elide el sonido gemebundo, en sentido unívoco, como configuración onomatopéyica, empero, comprende que es uno de los efectos remitidos por dicha epistología ("¿quién duda haber sido la confusión y el espanto mucho mayor que el destrozo y la pérdida, aunque fue tan grande?") (De Sigüenza, 1986, p. 163).

Nuestro polímata, atribuyendo la etiología a los desastres naturales no niega el sentir general, respecto al estadio genésico, tratando de posicionar la frase vox populi, vox Dei, en los condicionamientos antitéticos que remiten, o a la consolidación gubernamental, o a su desintegración acrática: "Oyóse por este tiempo una voz entre las (no 
sé si las llame venerables o despreciables) del vulgo, que atribuía a castigo de las pasadas fiestas") (De Sigüenza, 1986, p. 163). Ante el ordenamiento periclitado, nuevamente don Carlos atribuye que la volición, y la racionalidad, se conducen bajo reconocidos ejes deónticos, no sólo en el sentido cristiano, sino también en el orden gubernamental, que trata de mitigar una distensión imperial bajo un constructo epidíctico in bonam partem respecto a la representación virreinal. En este punto el yo testigo se difumina con el yo protagonista, aseverando que el alcázar ante tal disensión se encontraba, en cierta medida, relacionado a los ordenamientos que el mismo don Carlos fraguó, y los cuales se llevaron a cabo, bajo la estructura que permitía desdoblar la acepción teórica en práctica como objetivación política.

Resultó, de lo que yo procuré el que fuese con todo fundamento cuanto en él se propone el que comenzándose a quince de diciembre la limpia de las acequias, se concluyese, en moderado tiempo" (De Sigüenza, 1986, p. 169) [...] "Parecióme (después de haberlo premeditado por muchos días) que, para que no se anegasen otra vez los barrios occidentales de la ciudad, no bastaba esto y, proponiendo para conseguirlo una nueva acequia, aprobó su excelencia mi dictamen y me encargo estas obras") (De Sigüenza, 1986, p. 170).

Este apartado es una reminiscencia de su labor que, como la brida de oro, se eleva para engendrar un orden racional con el fin de desentrañar la etiología factual, y delimitar el creciente descontento. De este modo, nuestro polímata asevera una cartografía que implicaba una labor hidráulica emprendida en Santo Domingo y concluida en Chapultepec (al ser una afluente natural para la ciudad de México). Reconociendo, que a la inestabilidad se le hace frente, bajo una comprensión cuasi- simétrica de orden categorial:

De la mucha tierra que dio en dos varas de hondo, seis de ancho y tres mil seiscientos y veinte que tiene en su longitud, fortalecido de muchos sauces que en él planté, se formó un parapeto hacia la ciudad, para que, deteniéndose en él las aguas cuando fuesen pujantes las avenidas, corriesen por la zanja sin pasar a México [...] Lo primero que hice fue continuar la de Santo Domingo, desde el puente de las Tres Parroquias hacia el Poniente por el mismo lugar que tenía ante; proseguí por los barrios de Santa María Teocaltitlán, Atlampa y Tlacopan, hasta salir por detrás del Hospital de San Hipólito a la puente de Alvarado, que está en la arquería por donde viene el agua de Santa Fe; desde aquí, la guie por tajo nuevo a la puente que tiene calzada por donde desde la calle de San Francisco se va al Calvario y, atravesando el ejido de Zacatengo, acequia del Sapo y Ciénegas de Techalocalco que allí se hacen, se termina en la puente de los Cuartos, que es en la calzada de Chapultepeque. (De Sigüenza, 1986, p. 170)

Por su parte, en algunos fragmentos de la epístola, la loci descriptio, y la comprensión inteligible se ven subsumidas por una atribución catafática de la divinidad, es decir, la etopeya punible por la distención religiosa implica una iteración de la catástrofe. No se quiere decir con ello, que este proceso disfórico es propio de una incomprensión racional, al contrario, don Carlos se adhiere a un nosotros que desentraña la cronografía virreinal y refuerza el lazo programático de la religión respecto a las alusiones del diluvio:

habiendo sido por uno de aquellos medios de que Dios se vale para castigar a los impíos y reducir al camino de la justicia a los que lleva extraviados la iniquidad, yo no dudo que mis pecados y los de todos le motivaron a que, amenazándonos como padre con azote de agua, prosiguiese después el castigo con hambre por nuestra poca enmienda (De Sigüenza, 1986, p. 172).

Con posterioridad, la secuente catástrofe, se reintroduce, en la péndola de Sigüenza, dentro de un orden lógico (predicho por lunarios y almanaques); en primera instancia, se alude a los posicionamientos físico matemáticos, en segundo punto, se construye un cuadro inteligible bajo la etopeya de su tiempo, en tercera instancia, se fragua una constitución crónica categorizada en diversos niveles, de este modo, nuestro polímata sigue los postulados epistolográficos de Demetrio "se puede 
decir que cada uno escribe la carta como retrato de su propia alma. En cualquier otra forma de composición se puede ver el carácter del escritor, pero en ninguno como en el género epistolar" (Demetrio, 1996, p. 97).

Por ende, don Carlos, asevera que el 23 de Agosto de 1692 existió una superposición de la luna en el transito luminoso, produciendo un eclipse solar aproximadamente a las ocho y tres cuartos de la mañana, quedando la ciudad "no a buena, sino a malas noches, porque ninguna habrá sido, en comparación de las tinieblas en que, por el tiempo de casi medio cuarto de hora" (De Sigüenza, 1986, p. 173). Dicha écfrasis referencial, apela a ciertos parámetros visuales con el fin de que el destinatario, en su construcción noética, pueda hacer más complejo el acaecer pretérito. Nuevamente, el erudito se coloca en un posicionamiento privilegiado dentro del campo epistémico, delimitando la distención pública en su concepción moderna. Lo anterior se contrapone, mediante la ralentí narrativa, de la disforia general que remarca la incapacidad de entablar un orden categorial en las confluencias crónicas. A su vez, no se encontraba en confrontación directa con la omnipotencia, es decir, aunque la población nesciente apelaba a la salvación divina, don Carlos refocila en demasía y agradece al sumo celestial debido a que la manifestación física, puede ubicarse uranométricamente con instrumentos que amplifican la visualización del avistamiento.

Yo, en este ínterin, en extremo alegre y dándole a Dios gracias repetidas por haberme concedido ver lo que sucede en un determinado lugar tan de tarde en tarde y de que hay en los libros tan pocas observaciones, que estuve con mi cuadrante y anteojo de larga vista contemplando el sol (De Sigüenza, 1986, p. 173).

Con ello, don Carlos hace gala de sus conocimientos astronómicos, y afirma, mediante una écfrasis nocional, que el eclipse solar se da en cuadrante entre Mercurio (en una latitud de menor elevación), una constelación propia de la visión septentrional (Leo), y Venus (en una latitud de mayor elevación). Es probable que el más ingente fulgor, apercibido dentro del manto celeste, sea la estrella Regulus; por su parte, está claro que debido a que Mercurio y Venus se encuentran entre el binomio órbita terrestre/constitución solar, y que su periodo de órbita sideral es menor al de la Tierra (87 y 224 días respectivamente), las posibilidades de cierta cercanía en la uranometría septentrional, junto al astro Regulus, son plausibles. "Mediaba éste entre Mercurio, que apartado de él como cinco grados hacia el Oriente, se veía con el anteojo cómo estaba la luna en la cuadratura y en el corazón del León que demoraba al Ocaso, y más adelante Venus defalcada, estaba cubierto de estrellas el cielo por todas partes" (De Sigüenza, 1986, p. 173). De ahí, nuestro polímata arremete con la declaración experiencial, apelada por la astrología de su época, debido a que durante cerca de una hora el ambiente se mantuvo símil al invernal, aun cuando en México se encontrarán en una temporalidad veraniega (Junio-Septiembre): "y por último, desde las ocho y media hasta las nueve y media estuvo el aire tan frio y destemplado como por invierno, con que se verifica el aforismo de los astrólogos en que a los eclipses, y con especialidad a los del Sol, se atribuye esto" (De Sigüenza, 1986, p. 173).

Por su parte, el yo que enuncia apela a una novísima etiología como poli - causalidad para el motín público; con ello, está claro que la epístola de don Carlos, es un constructo "que se encuentra especialmente condicionado por la subjetividad, las selecciones de la memoria y las elecciones de la psique" (Krasniqui, 2014, p. 3), permitiendo comprender una faceta del proceso cognoscitivo en el polímata novohispano. Es decir, para Sigüenza existe una posibilidad de racionalizar la factualidad pretérita -presente, con el fin de atender las marcas de un presente dilatado. Así, encontramos dicha particularidad cuando don Carlos habla de la plaga que azotó el trigo por el chahuiztli (introducido como agente crónico bajo el nomen náhuatl y castellano). En el fragmento, es plausible que aluda a la etapa madura del Macrodactylus Mexicanus, que el mismo Sigüenza asevera ser símil a los Curculionidae (curculiónidos). Se debe considerar que el Macrodactylus Mexicanus tiene un área operatoria que incluye el altiplano mexicano, y su actuar se presenta en el mes de Mayo - Junio, o bien, conforme a las lluvias podría apercibirse hasta Julio (“Quién duda haberse originado nuestro chiahuiztli así de las muchas aguas del mes de julio, como de las nubes y neblinas casi continuas y de la calma que siempre hubo?”) (De Sigüenza, 1986, p. 173). 
Por ende, el modo en que operó en 1692 el Macrodactylus Mexicanus, como agente patógeno, puede estar relacionado con las lluvias ingentes que arroparon la parta central del virreinato. De aquí, don Carlos crea una écfrasis referencial, y trata de adentrar en su modalidad noética al destinatario, finalizando con una analogía: el agente patógeno asemeja al robigo vel rubigo (orín), teniendo como principio etiológico el chahuiztli (humedad), así, los campos se consumen con celeridad, cual si fuego se tratase, decantando en una frágil producción por causas fluviales, y como la imagen opaca del orín (robigo), causada por la infiltración líquida en los metales, del mismo modo, la eficacia del trigo se obscurece tras la catástrofe ("Extendiéndose esta peste de los trigos con la misma actividad con que el fuego abrasa todo y, si no fue el rubigo de los latinos, tuvo por lo menos con él un común principio") (De Sigüenza, 1986, p. 173). De esto se concluyen las écfrasis referenciales y noéticas, construidas bajo la péñola del novohispano, y erigidas bajo la instrumentación micro - y macro visual, permitiendo aducir que los nodos de una variación crónica, pueden ser concebidos, y posiblemente regulados, bajo el ímpetu racional.

Ante la escasez se determinó que se trajese de Celaya los elementos faltantes, pero, "oponíase a esta determinación no ser muy fácil el conducirlo, porque ni querrían los labradores (siendo los más de ellos pobres, y no teniendo recuas) traerlo a México, ni se sabía de donde se sacarían los reales para comprarlo" (De Sigüenza, 1986, p. 178). Con lo cual el virrey solicitó al capitán Pedro Ruiz de Castañeda que requiriera al alguacil mayor de Celaya, don Rodrigo de Rivera Maroto el traslado del maíz, "con la prontitud con que ejecutó este caballero cuanto se le encargó, pasaron de cuarenta y cuatro mil fanegas las que se aseguró y remitió por horas, y con esto y lo que se traía de Chalco y de Toluca, se iba pasando en México como mejor se pudo" (De Sigüenza, 1986, p. 178). La figura del virrey funge como nodo de la constitución virreinal, objetivada en la grafía epistolar bajo el aspecto epidíctico in bonam partem. En contraparte, la anamnesis, enfatiza el constituyente general de la turba réproba, destacando que los indígenas lideran el conglomerado (nótese que la mayor población se encuentra en este estrato), pero, no se niega su integración en la pléyade de castas, a criollos, descendientes de negros, mestizos, mulatos, y españoles, estos últimos con un epíteto negativo en demasía, debido a que en la eutaxia ${ }^{5}$, la categorización deóntica corresponde, en cierta medida, a su ordenamiento en el orden imperial.

Y lo de todas la plebes, por componerse de indios, de negros, criollos y bozales de diferentes naciones, de chinos, de mulatos, de moriscos, de mestizos, de zambaigos, de lobos y también de españoles que, declarándose zaramullos (que es lo mismo que pícaros, chulos y arrebatacapas) y degenerando de sus obligaciones, son los peores entre tan ruin canalla") (De Sigüenza, 1986, p. 178).

Sin embargo, la constitución epidíctica in malam rem no solo se ajusta al canon de estas particularidades, sino que también se adscribe a ciertas potestades del aparato virreinal, que, en su parva racionalidad, inscriben el errar a la distención pública. El caso, se encuentra relacionado al grano proporcionado por Puebla, que fue renegado por ciertas autoridades, a quienes don Carlos, el magnánimo filomomo, conduce al paredón de la sátira: "y con verdad informes, pues no contenían sino despropósitos de interesados y contradicciones manifiestas de los que, por tener obligación de haber leído a Plinio, Teofrasto, a Galeno, Dioscórides y a Columela, no debían decirlas por aplaudir a aquéllos" (De Sigüenza, 1986, p. 182). No obstante, el virrey, enterado de una disertación de Ambrosio de Lima, "médico de esta Corte, [y quien] había defendido contra los informes siniestros del Protomedicato la inocencia de este trigo en extremo bien, a diez y seis de enero de este año mandó pregonar su excelencia, motu propio" (De Sigüenza, 1986, p. 183). Sigüenza se burla en gran medida de dichas autoridades, adjudicándoles el atributo de protomédicos in malam partem, es decir, eran quienes ejercían con licencia, pero para el erudito, bajo falacias de autoridad (aunque cabe la posibilidad, que este suceso exteriorizará la intriga de sectores beneficiados por la carestía del grano). Ahora bien, el culmen de la revuelta se da en dos áreas en específico, en las indígenas ligadas a la compra - venta de tortillas, y en las pulquerías; sea de paso este fragmento es en suma interesante, debido a que don Carlos, bajo este narrador presencial, da cuenta 
de la poli - causalidad en el desarrollo el acaecer. En este punto don Carlos asevera que una cuartilla de maíz de siete reales, brindaba un promedio de trescientos cincuenta tortillas (con costo de catorce reales y medio), a lo que el polímata deduce, que si doce tortillas se adquirían por medio real, y la mano de obra se valoraba en real y medio, entonces catorce reales y medio nos da un total de trescientos cuarenta y ocho tortillas con un sobrante de dos. Finalmente, Sigüenza concluye que al restar la mano de obra y el costo de la cuartilla de maíz se obtenía una ganancia de seis, o seis y medio reales aproximadamente, excedente que los maridos lo gastaban en las pulquerías. Infiriendo nuevamente al destinatario, en modalidad ecofonémica, con el fin de persuadirlo de que la respuesta a la desgracia aflora en los límites de la naturaleza humana y el libre albedrio:

¿cómo podían perecer, como decían a gritos, cuando de lo que granjeaban con ellas no sólo les sobraba para el sustento en que se gasta poco, como todos saben, sino para ir guardando, $y$ esto prescindiendo del continuo de los oficios y jornales de su marido? Luego, sólo esta ganancia tan conocida, y no el hambre, las traía a la alhóndiga en tan crecido número, que unas a otras se atropellaban para comprar maíz; luego, en ningún otro año les fue mejor. A medida del dinero que les sobraba, se gastaba el pulque y, al respecto de lo que éste abundaba entonces en la ciudad) (De Sigüenza, 1986, p. 185).

Para nuestro polímata, el excedente ya mencionado permitía una afluencia en la pulquería, donde no sólo indígenas sino lo más bajo de la plebe se reúne, instaurando las directrices para el motín. En especial, los habitantes de Tlatelolco, lugar que se ha distinguido siempre por su disensión con el aparato gubernamental.

Los indios que andaban más solicitados en estas pláticas, según se supo después, eran los de Santiago, barrio que es ahora de la ciudad y mitad de ella (con el nombre de Tlatelolco), cuando en tiempo de la gentilidad, tenía señor diverso del de México”) (De Sigüenza, 1986, p. 187).
Don Carlos aviva la distinción entre México - Tenochtitlan / poderío virreinal, y Tlatelolco / barrio de Santiago, bajo una ratiocinatio digresiva, que funge analépticamente ante la caída del tlatelolca Moquíhuix ante el Huey Tlatoani Axayácatl en el año de 1473, es decir, existiendo una conceptualización crónica de la distentio temporis puplica $^{6}$. De modo secuente, es un paralelo de la confrontación entre el ordenamiento gubernamental y una escisión geo-política en dos puntos distantes temporalmente.

Y si esto es así (como verdaderamente lo es, pues se apellidaban con el nombre de santiagueños en la fuerza del alboroto), no es ésta la vez primera que han intentado destruir a México donde al presente vivimos; pero ojalá, como entonces procedieron contra ellos y contra su señor Moquíhuix, los mexicanos, aun siendo bárbaros, se hubiera hecho ahora con unos y otros (De Sigüenza, 1986, p. 187).

Con ello, apreciamos que el eje escritural de don Carlos, respecto al enrarecimiento del aparato virreinal es producto "de una coyuntura que resulta de un enjambre de causas diversas y su caracterización depende de la combinación de muchos componentes y acontecimientos" (Héau, 2010, p.7). Dadas las condiciones anteriores, acaeció la fecha para el motín el domingo de Corpus Christi (8 de Junio de 1692), donde no sólo se fragmentó el orden gubernamental, sino que, a su vez, se trastocó la celebración de la eucaristía, donde factualidad y eternidad son traspasadas por la volición general de la población. En las horas primigenias del movimiento, el filomomo hace gala de su péndola para advertir que una indígena, tras ser pisada en la búsqueda de grano, adquirió el epíteto de occisa ( $\dot{i}$ ?), y con ello, fue trasladada al mercado del Baratillo, momento, en el que don Carlos introduce un perspicaz diálogo (discurso recto), entre dos estudiantes que observaban detenidamente a la indígena (“iMirad, hombre, cómo está sudando la pobre muerta! Allegóse el otro a ella lo más que pudo y respondiéndole así: !No está muy muerta, porque pestañea un poco y tragó saliva!") (De Sigüenza, 1986, p. 194). El sabio novohispano, adjudica la racionalidad a la voz de los estudiantes, que tiene como 
contraparte a la polifonía de la muchedumbre: “QQué sabéis vosotros de cómo están los muertos, perros estudiantes de modorro?, les dijo la india, que les oyó la plática; ahora moriréis todo México, como ella está" (De Sigüenza, 1986, p. 194). Dicho relato, se presenta al destinatario como emanación de una factualidad inherente a la modulación crónica de su presente, apelando a una recopilación de orden vivencial, siendo anamnesis de segundo orden, que llega como écfrasis referencial y polifonía en la lectura del estratega:

Refirióme esto un hombre honrado que se halló presente, y me aseguró, con juramento que le pedí, no sólo ser verdad lo que los estudiantes dijeron sino el que poco antes le oyó decir a la muerta que la cargaran bien ¡Estos son los indios!) (De Sigüenza, 1986, p. 194).

Con ello, el acaecer fluye sin cesar, como si la infinidad de cuerpos se desglosará en la péndola del polímata y se enfrentara con la fas del lector; de esta forma, se refiere que a las seis de la tarde comenzó la trifulca frente al balcón de la virreina, y es el mismo Sigüenza, que se introduce en una diégesis vivencial, es el yo testigo que apercibe en persona, y trata de traslapar esa experiencia en una loci descriptio, que se verá enriquecida por dicha etopeya cronográfica. En dicha reconstrucción, la polifonía toma leves diferencias en la pronunciación de los agentes históricos, debido a que los negros enfatizan la finalidad del orden virreinal, y los indígenas, son más radicales, al confrontar directamente las castas que se encuentran por encima de ellos, exceptuando, la génesis propiciada en el lazo consanguíneo entre sí mismos, y los venideros de la región ibérica.

Traían desnudas sus espadas los españoles y, viendo lo mismo que allí me tenía suspenso, se detenían; pero los negros, los mulatos y todo lo que es plebe gritando: ¡Muera el virrey y cuantos lo defendieren!, y los indios: «!Mueran los españoles y gachupines que nos comen nuestro maíz!» (De Sigüenza, 1986, p. 198).
En este punto, el héroe cortesiano desvanece ante la insistencia indígena, que rememora su finitud fisiológica, con lo cual, se presenta un sentido de la historia muy interesante: se reconoce que los procesos crónicos nunca son regulares, y que existe el mudar de ejes anteriormente vigentes.

Y exhortándose a tener valor, supuesto que ya no había otro Cortés que los sujetase, se arrojaban a la plaza a acompañar a los otros y a tirar piedras. ¡Ea, señoras! ¡vamos con la alegría a esta guerra, y como quiera Dios que se acaben en ella los españoles, no importa que muramos sin confesión! ¿No es nuestra esta tierra? Pues ¿Qué quieren en ella los españoles? (De Sigüenza, 1986, p. 198).

La distención pública al haber trastocado el orden virreinal y el axis mnemotécnico de la fundación novohispana, se presenta a quebrantar la ponderación religiosa, al recibir de modo violento a una parafernalia eclesial, en la que se encontraban nuestro polímata y el arzobispo. En este punto, el motín, donde no existe una sola casta, se encuentra en su culmen al confeccionarse de diversas disensiones respecto a la estructura imperante. Nuestro polímata, funde la polifonía en una sinérgica composición que se traslapa por el espacio virreinal; caso de suma relevancia, es que no impele la totalidad de los actos a los indígenas o a otra casta, sino que comprende que la cualidad acrática se debe más a una gama de variaciones crónicas, que a una fútil mono- causalidad.

En materia tan en extremo grave como la que quiero decir, no me atrevería a afirmar asertivamente haber sido los indios los que, sin consejo de otros, lo principiaron, o que otros de los que allí andaban, y entre ellos españoles, se lo persuadieron. (De Sigüenza, 1986, p. 200)

La écfrasis referencial, nuevamente se aviva en la polifonía del anónimo, que encarna su existencia en el conglomerado mismo que apelaba a un óbito consumado del virrey, así don Carlos integra castas, tono, e intencionalidad polifónica, con el fin de que las albricias y los vituperios sean dirigidos al poder metropolitano, 
al barrio de Santiago, y al pulque. El filomomo hace de las suyas, y en su posición de criollo, confronta la patria mexicana con la potestad peninsular; es decir, ponen en la misma conceptualización a la causa de la revuelta (pulque), a uno de los agentes involucrados (santiagueños), al poder ausente (el rey), y a la advocación de la virgen del Rosario en donde la hispanidad rebosa por su relación con la batalla de Lepanto ( ${ }_{¿}$ Por qué no se aclama a la virgen María?). Con ello, Sigüenza constituye como valor antitético al estema preponderante, que tenía como axis capital al conde Gaspar de la Cerda Sandoval Silva y Mendoza conde de Galve:

No oyéndose entre los sediciosos sino: ¡Muera el virrey y el corregidor!, y estando ya ardiendo el palacio por todas partes, pasaron a las casas del Ayuntamiento, donde aquél vivía para ejecutar lo propio", aunque el corregidor y su esposa no se encontraban en dicha morada, [...] con ello, "no se oía otra cosa en toda la plaza, sino «!Viva el Santísimo Sacramento ¡Viva la virgen del Rosario !Viva el rey! ¡Vivan los Santiagueños! ¡Viva el pulque!» (De Sigüenza, 1986, p. 202).

Así, la polifonía de la turba se transforma en sonoridad soez, de sentido anfibológico, y con connotaciones que fragmentan el uso más racional del lenguaje: "y esto, no tan desnudamente como aquí lo escribo, sino con el aditamento de tales desvergüenzas, tales apodos, tales maldiciones contra aquellos príncipes, cuales jamás me parece pronunciaron hasta esta ocasión racionales hombres" (De Sigüenza, 1986, p. 202). En este punto, don Carlos transfigura los agentes históricos en un periplo virgiliano, él redime, junto con sus coadyuvantes, las acciones de la turba iracunda, fundiendo una écfrasis referencial y otra nocional en su péndola, al perpetuar materialmente una memoria que aflora como símbolo de poder:

Entre la pesadumbre que me angustiaba el alma, se me ofreció el que algo sería como lo de Troya, cuando la abrasaron los griegos (De Sigüenza, 1986, p. 202) [...] hice espontánea y graciosamente y sin mirar al premio, cuando, ya con una barreta, ya con una hacha, cortando vigas, apalancando puertas, por mi industria se le quitaron al fuego de entre las manos no sólo algunos cuartos de palacio, sino tribunales enteros y de la ciudad su mejor archivo.) (De Sigüenza, 1986, p. 206).

Por ende, el plano inteligible que don Carlos fraguó, con anterioridad respecto a los nodos poli -causales de la afrenta, son la encarnación de Laocoonte; así, él y quienes participan en la lid frente al alboroto se transfiguran en Eneas portando a Anquises (aparato virreinal), logrando destenderse en el espacio - tiempo, al asegurar la pervivencia del constructo novohispano:

En estas cosas se pasó la noche, pero no era necesario que amaneciese para ver y llorar con suspiros dolorosos lo que el fuego hacía (De Sigüenza, 1986, p. 212) [...] pero con la actividad con que don Juan de Aguirre y don Francisco de Sigüenza, mi hermano, introdujeron, aquél en otras canoas y éste en las recuas que halló muy cerca, no sólo suficiente sino sobrado maíz (De Sigüenza, 1986, p. 214).

Retomados los espacios, y la regulación crónica, se procede por un lado a tratar de solventar el abasto de maíz, y por el otro, a la omisión polifónica de los discordantes, llamando a la supina supresión de la ablación fónica:

Habiéndose cogido cuatro indios en los mismos cuarteles de palacio al ponerles fuego y confesando, sin tormento alguno, haber sido cómplices en el tumulto y cooperado al incendio, menos a uno que con veneno la noche se mató a sí mismo, el miércoles once por la mañana los arcabucearon; ahorcaron a cinco o seis; quemaron a uno y azotaron a muchos en diferentes días (De Sigüenza, 1986, p. 216)

Infinidad de voces ha sido contenidas, con lo cual, la tonalidad del polímata gradualmente se presenta como evocación anamnética, obteniendo una distención temporal respecto a las sediciones futuribles, que se presentan como un pasado - presente, dentro del estema crónico (esta escasez también se manifestó en Tlaxcala el 16 de Junio, empero, el aparato virreinal actuó con 
celeridad y logró apaciguar el tumulto). Finalmente, la peroratio concluye con una conminación, para que el destinatario tenga en cuenta, y divulgue, la funcionalidad de dicha razón histórica; donde los posicionamientos inteligibles estructuran la realidad y posicionan conceptualmente a la población bajo el poderío de una determinada potestad. Con ello, la factografía de don Carlos, como fundamento de la razón, formó parte de los procesos constituyentes, en lo que respecta a la res publica, entre los que se encuentran tanto la prohibición del pulque, como la expulsión de los indios fuera de la ciudad. Lo que implicó que al final de la jornada no se tocara "la oración de ánimas, ni en tres días se replicó a misa, siendo la octava de Corpus. ¡Queríanse sofocar todos los ruidos que pudieran provocar un alboroto!" (Obregón, 2015, p. 332). Por su parte, a partir del marte 10 de Junio "echaron bando, para que no anduvieran juntos arriba de cinco indios, y pena de la vida. El mismo día se puso horca nueva" (Obregón, 2015, p. 332), así, se aprisionaron varias castas con el fin de que se cediera lo expoliado, "entregándola a sus dueños; más de setenta mil pesos en moneda que se había encontrado" (Obregón, 2015, p. 332). Con posterioridad, en la mañana del 11 de Junio "se arcabucearon tres indios de los incendiarios; debiendo haber sido cuatro, pero uno se mató antes con veneno. Por la tarde les cortaron las manos a los difuntos, clavándolas en unos palos en la misma horca” (Obregón, 2015, p. 332). Siendo este uno de los últimos claroscuros del motín de 1692, que sacudió los cimientos virreinales y se formalizó en la péndola de nuestro egregio pensador.

\section{Bibliografía}

Arcos, T. (2008). De Cicerón a Erasmo: La Configuración de la Epistolografía como Género Literario, en Boletín Millares Caro, $\mathrm{N}^{\circ}$ 27, Gran Canaria: UNED

Campaña, O. (2006). Determinación de Agresividad de Hongos Entomopatógenos para Macrodactylus Sp, Ecuador: Tesis de Grado Previa para la Obtención de Título de Ingeniero Agrónomo
De Covarrubias, S. (1611). Tesoro de la Lengua Castellana o Española. Madrid: Luis Sánchez impresor del Rey

De Sigüenza, C. (2003). Paraíso Occidental. México: CONACULTA

De Sigüenza y Góngora, C. (1986). Teatro de Virtudes Políticas / Alboroto y Motín de los Indios de México. México: UNAM / Porrúa

Demetrio. (1996). Sobre el Estilo. Madrid: Editorial Gredos

Héau, C; Rajchenberg, E. (2010). "Diez años de Revolución: Francia 1789-1799 y México 1910-1920”, en La Revolución Mexicana y las Revoluciones Modernas, Los Historiadores y la Historia para el Siglo XXI. México: ENAH / INAH / CONACULTA / Ediciones Navarra

Krasniqui, F. (2014). El Texto Epistolar: Un Punto de Intersección entre los Géneros Discursivos y los Géneros Literarios, en Revista Electrónica de Estudios Filológicos, $\mathrm{N}^{\circ}$ 26, Murcia: Universidad de Murcia

G. Maestro, J. (2012). El Origen de la Literatura: ¿Cómo y por qué Nació la Literatura? España: Editorial Anthropos

Obregón, L. (2015). Don Guillén de Lampart: La Inquisición y la Independencia en el siglo XVII. México: CONACULTA

Oviedo, M. (2007). Historia de la Literatura Hispanoamericana / 1.- De los Orígenes a la Emancipación. Madrid: Editorial Alianza

Pimentel, L. A. (2003). Ecfrasis y lecturas iconotextuales., Poligrafías - Revista de Literatura Comparada, $\mathrm{N}^{\circ}$, México: UNAM 